\title{
Plant Community Composition and Structure of Chenab Valley in a Part of Nanda Devi Biosphere Reserve
}

\author{
Abhinaba MAJUMDAR, Bhupendra S. ADHIKARI* \\ Wildlife Institute of India, Department of Habitat Ecology, P.O. Box 18, Chandrabani, Dehradun \\ 248 001,Uttarakhand, India; adhikaribs@wii.gov.in (*correspondingauthor)
}

\begin{abstract}
The present paper deals with the vegetation communities and their diversity patterns in Chenab valley, the buffer zone of Nanda Devi Biosphere Reserve (NDBR) in Chamoli District of Uttarakhand, India. A total of 42 sites were selected randomly based on the landform heterogeneity of the area. Eight forest communities with overlap among vegetation types and also various plant associations were noticed through Principal Component Analysis (PCA) following PAST program and two shrub communities identified separately were, Berberis and bamboo. The range of density in various forest communities was from 203-545 trees ha ${ }^{-1}$ and total basal area from $17.5-71.7 \mathrm{~m}^{2} \mathrm{ha}^{-1}$. The range of species richness of tree layer, shrub layer and herb layer was from 2-14, 1-10 and 4-14 and diversity from 0.693-2.304, 0.5142.052 and 1.202-2.583, respectively. The distribution pattern of trees, shrubs and herbs shows that the species were evenly distributed in most of the sites and the $B$-diversity of the present study area is 7.4. Rhododendron and Taxus, the undercanopy species facilitated the regeneration of Chimnobambusa falcata, while the conversion of lower girth class individuals to higher girth class individuals is steady and progressive. Though, evergreen and deciduous species had good population of seedlings and saplings, but the conversion to next girth class was very poor due to the high anthropogenic pressure. The present study reveals that the forest vegetation in Chenab valley is better than that of other parts of Nanda Devi Biosphere Reserve, for which conservation strategies have been discussed in the paper.
\end{abstract}

Keywords: $\beta$-diversity, community, grazing, Nanda Devi Biosphere Reserve, total basal area

\section{Introduction}

The Himalaya is one of the richest biogeographic zones in India and is well known for its ecological, hydrological, aesthetic and socio-cultural values (Mani, 1974). The location, topography and climate of this complex system have endowed it with rich and diverse life form. The large scale surface removal due to geological instability and cyclic climate change has greatly influenced the floral and faunal communities. The disturbance can alter environmental conditions by changing light availability and soil condition, which are mainly due to heavy anthropogenic pressure (Fredericksen and Mostacedo, 2000). The chronic form of disturbance in these forests often led to inadequate recovery of ecosystems due to continuous exploitation of the forests (Singh, 1998). The recurrent anthropogenic intervention such as fuel wood, fodder, litter and non-timber forest products (NTFP) collection, as well as grazing, browsing and trampling largely by livestock can substantially lead the habitat alteration of the species (Pandey and Shukla, 1999).

Garhwal Himalaya has relatively a mixture of dry and moist temperate climate, which influences the growth and vitality of the forests through the water balance in the watersheds. Chamoli District in Uttarakhand state harbors the rich and varied flora, which has been of great attrac- tion for the professional collectors, ecologists and as well as amateur enthusiast. The occurrence of large number of species in the area and richness of the flora has rendered the district a botanical paradise. The lower Chenab valley, a buffer zone of Nanda Devi Biosphere Reserve forms the most prominent ecological boundary, where sub-alpine forest terminates. In many areas the presence of high altitude oak (kharsu oak, Quercus semecarpifolia), maple (Acer caesium), conifer (silver fir, Abies pindrow) and deciduous species (birch, Betula utilis) reach up to timberline. The common montane bamboo (Thamnocalamus spathiflorus) is prevalent in the canopy gaps (Puri et al., 1989).

The area above treeline is marked by a zone of stunted trees (krummholz) and shrubs with associate species like Salix, Rosa, Cotoneaster and Berberis. The structure and composition of high altitude forests in west Himalaya has been described (Champion and Seth, 1968; Singh and Singh, 1992) and richness and diversity of forest ecosystems by several workers (Adhikari et al., 1991, 1998; Bhandari et al., 1997; Dhar et al., 1997; Hussain et al., 2008; Kumar et al., 1997; Kunwar and Sharma, 2004; Rikhari et al., 1991; Saxena and Singh, 1984) in last few decades. The Garhwal Himalaya is witnessed to a faster place of modernization and development due to various activities, viz. coming up large scale dam construction, pilgrimage, widening of roads and eco-tourism. Such signs of 
46

stretch and strain are now discernible in its inhabitants as also the whole environment (Chadha, 1998).

The Nanda Devi Biosphere Reserve (NDBR) in the western Himalayas is one of the important protected areas in India, has two core zones, namely Nanda Devi NP and Valley of Flowers NP. Both the NPs established in 1982 and designated as World Heritage Sites by UNESCO in 1988 and 2005, respectively in the recognition of their biological and cultural diversity. An assessment of the present status of vegetation in the region is important as it will not only enable us to assess the conservation aspects of this unexplored valley, which have recently been included in Nanda Devi Biosphere Reserve, but also to understand the likely impacts of developmental activities in the area for future management of this very important buffer zone.

\section{Materials}

\section{Study area}

The study area is located in Chenab valley, the buffer zone of Nanda Devi Biosphere Reserve (NDBR) in Chamoli District of Uttarakhand. The Chenab valley and adjacent areas of village Thang are contiguous with Urgam Reserve Forest in southeast and Badrinath Forest Division in northeast. Joshimath Forest Division of NDBR and the area specified for Vishnuprayag Hydel Project are in the eastern boundary of Thang village (Fig. 1). The village Thang, which is spread over the entire study area (ca. 20 $\mathrm{km}^{2}$ ) with its six winter hamlets, viz. Mulia (2050 m), Malia (2100 m), Kanakot (2200 m), Guar (1700 m), DarunGhiwani $(2700 \mathrm{~m})$ and Danedar $(2500 \mathrm{~m})$ is inhabited by 254 families with 1700 souls. According to Champion and Seth (1968) the present study area harbours forests viz., evergreen broadleaved, deciduous broadleaved, coniferous, mixed broadleaved-coniferous and sub-alpine forests. The valley and adjacent forest area rich in endan-

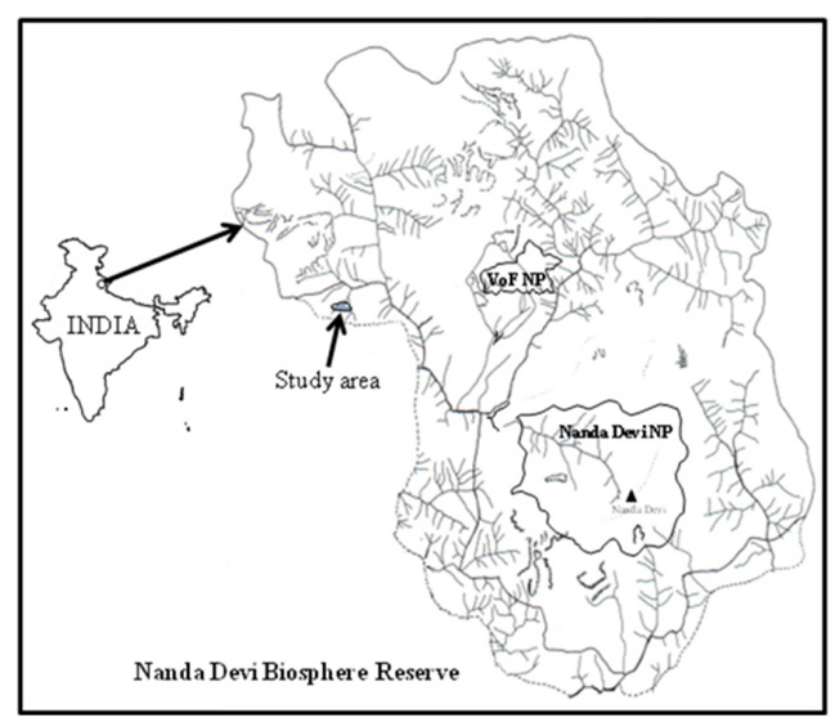

Fig. 1. Location of study area in Nanda Devi Biosphere Reserve, Uttarakhand gered and endemic species e.g., Musk deer (Moschus Chrysogaster), Himalayan Tahr (Hemitragus jemlahicus), Common leopard (Panthera pardus), Asiatic black bear (Ursus thibetanus), Serow (Nemorhaedus crispus), Royles' Pika (Ochotona roylei) among mammals and Monal (Lophophorus impeyanus), Koklas (Pucrasia macrolopha), Kalij (Lophura leucomelanos), Snow Partridge (Lerwa lerwa) and Himalayan Snowcock (Tetraogallus himalayensis) among birds. Although, agriculture has been primary source of subsistence economy for the local people of the area and enjoy unrestricted access due to traditional rights to use the natural resources, such as fuel wood and fodder collection along with non-timber forest products and use the area for livestock grazing. Exploitation of endangered medicinal plants (Dactylorhiza hatagirea, Podophyllum hexandrum, Picrorhiza kurooa) and pastel green (foliose lichen, locally known as Jhula) are the major concern of management.

The climate of the study area is typically the West Himalayan temperate and alpine type and divided in to five distinctive seasons, viz. spring (April), summer (MayJune), rainy (July-September), autumn (October-December) and winter (December-March). Precipitation is moderate over most of the year, while concentrated during monsoon and during winters the precipitation was in the form of snow and higher elevation areas experience heavy to moderate snowfall. The rocks in the area fall within the Central Himalayan Zone or Central Crystallines (Heim and Gansser, 1939). With increasing elevation the soil texture becomes finer, especially above $2000 \mathrm{~m}$ and a weak podzolization may occur at and around timberline (Singh and Singh, 1992).

\section{Methods}

A short reconnaissance trip for 3-4 days was made in the beginning in Chenab Valley and the adjacent forests of Thang village. The characteristic forest types were identified and within each identified forest different sites ( 1 hectare each) were selected for further data collection based on the extent of forest area. The site specific characters such as altitude, latitude, longitude, aspect, slope, canopy cover and condition of litter and soil were recorded. The data collection was done through systematic random sampling by laying quadrats (Misra, 1968). In each site ten, $10 \times 10$ $\mathrm{m}$ random quadrats were laid for the enumeration of trees (individuals $>31.5 \mathrm{~cm}$ circumference at breast height (cbh)). Within each $10 \times 10 \mathrm{~m}$ quadrat, $5 \times 5 \mathrm{~m}$ quadrat for saplings (10.5-31.4 cm cbh at $1.37 \mathrm{~m}$ ) and shrubs and four, $1 \times 1 \mathrm{~m}$ quadrats for herbs were laid. The density, frequency and total basal area was calculated (Misra, 1968; MullerDombois and Ellenberg, 1974), however, Importance Value Index (IVI) was calculated by summing up the relative values of density, frequency and total basal area (Curtis, 1959). The Principal Component Analysis (PCA) was performed to explore the patterns of forest communities 
and the species distribution following the PAlaeontological STatistics (PAST) program (Hammer, 2002) and the data matrix used for PCA was IVI values of tree species at each site.

The species diversity was determined by using Shannon-Wiener information function $\left(\mathrm{H}^{\prime}\right.$, Shannon and Wiener, 1963) and richness (Menhinick's Index) as given in Maguran (1988).

$$
\mathrm{H}^{\prime}=-\sum_{i=1}^{s}(p i)(\ln p i)
$$

Where $s=$ the number of species in the sample, $p i=$ relative abundance of $\mathrm{i}^{\text {th }}$ species $(\mathrm{ni} / \mathrm{N}), \mathrm{N}=$ total number of individuals of all kinds, $\mathrm{ni}=$ number of individuals of $\mathrm{i}^{\text {th }}$ species and $\ln =$ natural $\log$.

The beta $(\beta)$ diversity is computed to measure the rate of species change across the stands (Whittaker, 1960).

$\beta$ diversity $=S c / s$

Where, $\mathrm{Sc}$ is the total number of species encountered in the entire study area and $s$ is the average number of species per stand.

The data collected for circumference was pooled for deciduous and evergreen species and girth classes were made arbitrarily to know the regeneration status following Ralhan et al. (1982) and Rikhari et al. (1991).

\section{Results}

\section{Community composition}

A total of 42 sites were randomly selected in Chenab valley of Nanda Devi Biosphere Reserve. Eight forest communities were identified through Principle Component Analysis (PCA; Fig. 2) and some of them are shown in Photo 1. Although, the overlap among vegetation types and also various plant associations were noticed in the ordination space. The first axis explained $38.82 \%$ of the variance and the second axis $11.95 \%$. The first five major forest communities of the study area are shown with 95\% ellipses. However, two shrub communities were also recorded from the study area, which were dominated by Berberis and Chimnobambusa, respectively.

The forest types are separated based on altitudinal gradient and association of tree species (Fig. 2a). It was noticed that eight major forest types occupied the study area viz. alder mixed forest, tilonj oak-mixed forest, walnut-mixed forest, mixed forest, kharsu oak forest, kharsu oak-yew forest, kharsu oak-birch forest and kharsu oak-mixed forest. Among these forests the maximum similarity was between kharsu oak dominated forests, while tilonj oak-mixed forest and alder mixed forest similarity was quite low. The species contributing more for tilonj oak-mixed forest were A. pictum, C. jacquemontii, L. umbrosa, A. indica, C. viminea, L. ovalifolia and C. australis; for alder-mixed forest the species like $R$. arboreum, $C$. deodara, P. pashia, A. pindrow, Q. leucotrichophora and A. caesium were the major contributor, however, kharsu oak forms the forest with T. wallichiana and B. utilis separately in subalpine region (Fig. 2b).
Alder-mixed forest

The total tree density of alder-mixed forest was 343 trees ha ${ }^{-1}$, of which $26 \%$ contributed by Alnus nepalensis (Tab. 1). The total basal area of the forest was $23.9 \mathrm{~m}^{2} \mathrm{ha}^{-1}$ and Q. leucotrichophora contributed the maximum (37\%) followed by $A$. nepalensis (26\%; Tab. 1), while the IVI value of Alnus nepalensis wasmaximum (79.9). The total snag density of the forest was $33.3 \pm 13.3$ trees ha $^{-1}$. The total tree sapling density of the forest was 13.3 individuals ha ${ }^{-1}$ and Ficus rumphii was the only species (Tab. 2) and the total tree seedling density was 1047 individuals $\mathrm{ha}^{-1}$, of which A. pindrow contributed the maximum (39\%) followed by C. deodara (33\%). The total shrub density was 4760 individuals ha ${ }^{-1}$, of which Reinwardtia indica accounted for $19 \%$ followed by Rubus ellipticus (18\%). The total herb density of the forest was 24 individuals $\mathrm{m}^{-2}$ and Fragaria and Galium contributed the most (Tab. 2).

\section{Tilonj oak-Mixed forest}

The total tree density of tilonj oak-mixed forest was 490 trees ha ${ }^{-1}$, of which Q. floribunda contributed $22 \%$ and the total basal area was $53.0 \mathrm{~m}^{2} \mathrm{ha}^{-1}$, of which $39 \%$ contributed by $Q$. floribunda (Tab. 1). The dominant tree species was Q. floribunda with maximum IVI (82) followed by Aesculus indica (43). The total tree sapling density of the forest
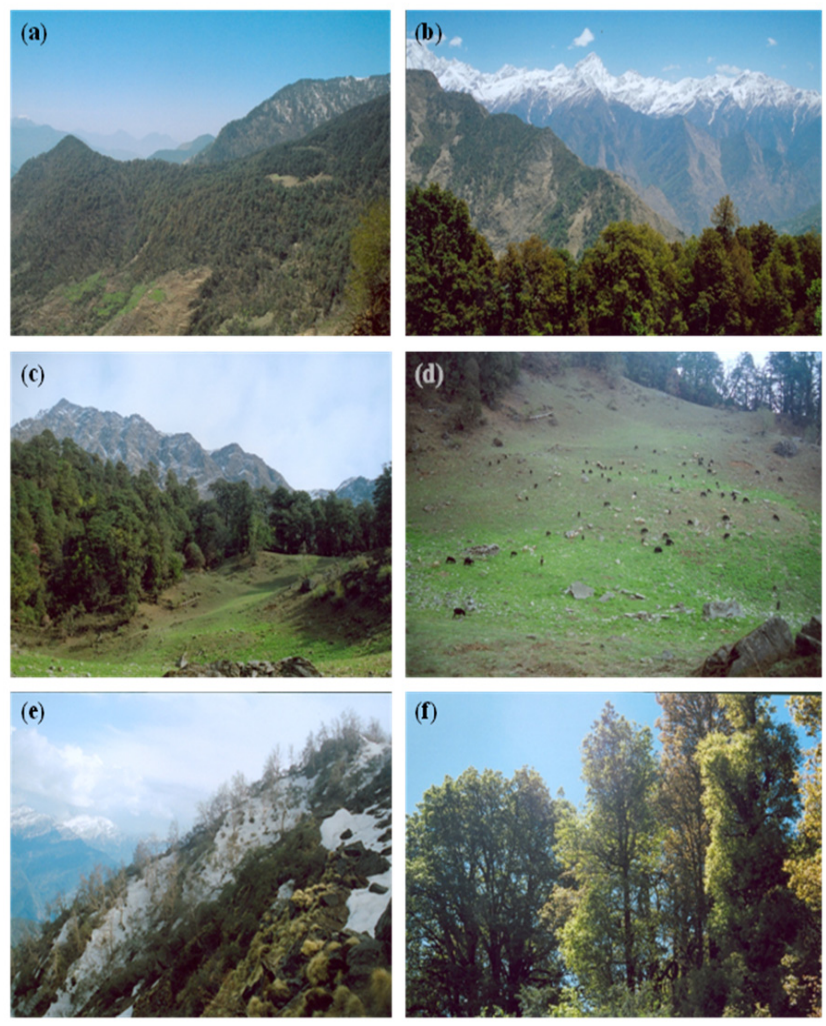

Photo 1. View of Chenab valley with agricultural fields along with evergreen broadleaved forest (a), Quercus semecarpifolia forest in the foreground and snow clad peaks on opposite slopes (b), a view of Dhor meadow along with Quercus semecarpifolia forest on the edge (c), grazing pressure in Selamghetta meadow (d), timberline forming Betula utilis forest in steep slopes (e), and deciduous (Acer spp.) forest (f) 

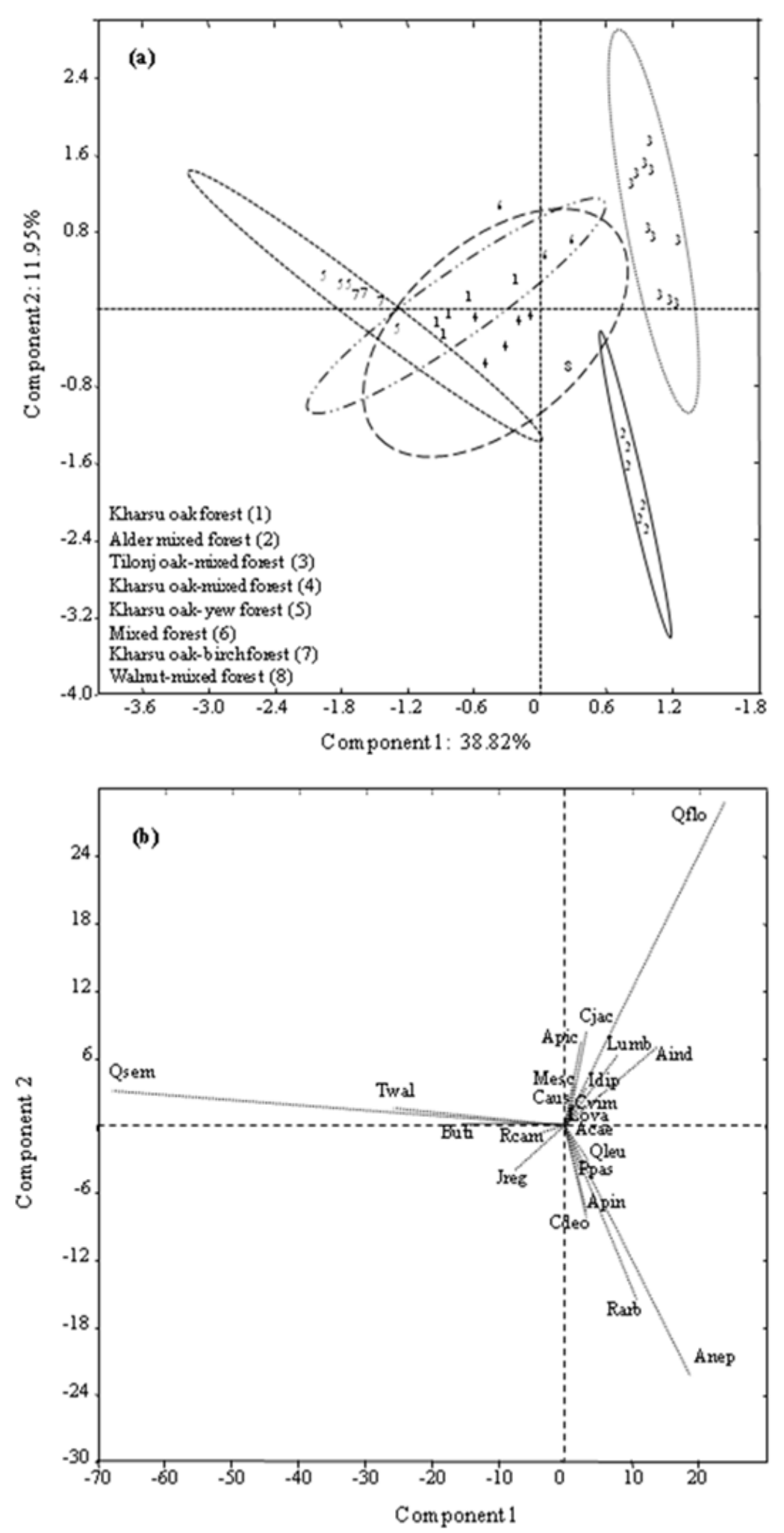

Fig. 2. Forest communities in Chenab valley identified through Principle Component Analysis. The abbreviations used in Fig. (2a) 1: Kharsu oak forest, 2: Alder-Mixed forest, 3: Tilonj oak-Mixed forest, 4: Kharsu oak-Mixed forest, 5: Kharsu oak-Yew forest, 6: Mixed forest, 7: Kharsu oak-Birch forest and 8: Walnut-Mixed forest, in Fig. (2b) Qsem: Quercus semecarpifolia, Qflo: Q. floribunda, Qleu: Q. leucotrichophora, Lumb: L. umbrosa, Idip: I. dipyrena, Mesc: Myrica esculenta, Caus: Celtis australis, Rarb: Rhododendron arboreum, Rcam: R. campanulatum, Twal: Taxus wallichiana, Buti: Betula utilis, Jreg: Juglans regia, Cdeo: Cedrus deodara, Apin: Abies pindrow, Anep: Alnus nepalensis, Ppas: Pyrus pashia, Cvim: Carpinus viminea, Lova: Lyonia ovalifolia, Acae: Acer caesium, Apic: A. pictum and Aind: Aesculus indica 
Tab. 1. Density, Total Basal Area (TBA) and Importance Value Index (IVI) of different species in different forest communities

\begin{tabular}{|c|c|c|c|}
\hline Species & $\begin{array}{c}\text { Density } \\
\left(\text { trees ha }^{-1}\right)\end{array}$ & $\begin{array}{c}\text { TBA } \\
\left(\mathrm{m}^{2} \mathrm{ha}^{-1}\right)\end{array}$ & IVI \\
\hline \multicolumn{4}{|c|}{ Alder mixed forest } \\
\hline A.pindrow & $30.0 \pm 5.8$ & $1.2 \pm 0.3$ & $21.6 \pm 2.0$ \\
\hline A. nepalensis & $90.0 \pm 13.6$ & $6.2 \pm 0.7$ & $79.9 \pm 5.5$ \\
\hline C. deodara & $35.0 \pm 14.4$ & $1.4 \pm 1.4$ & $23.4 \pm 9.6$ \\
\hline Q. leucotrichophora & $80.0 \pm 4.7$ & $8.8 \pm 0.4$ & $17.6 \pm 6.7$ \\
\hline R. arboreum & $56.7 \pm 11.8$ & $2.2 \pm 0.3$ & $49.2 \pm 10.2$ \\
\hline Others & $51.7 \pm 9.9$ & $4.2 \pm 1.9$ & $108.3 \pm 27.7$ \\
\hline Total & 343.3 & 23.9 & \\
\hline \multicolumn{4}{|c|}{ Tilonj oak - mixed forest } \\
\hline A. caesium & 5.5 & 0.6 & 3.1 \\
\hline A. pictum & $23.6 \pm 9.2$ & $3.1 \pm 1.1$ & $12.8 \pm 4.9$ \\
\hline A. indica & $53.6 \pm 6.5$ & $10.2 \pm 1.5$ & $42.5 \pm 5.6$ \\
\hline A. nepalensis & $32.7 \pm 3.5$ & $3.1 \pm 0.5$ & $21.7 \pm 2.3$ \\
\hline C. viminea & 8.2 & 0.5 & 3.2 \\
\hline C. australis & $21.8 \pm 0.2$ & $1.5 \pm 0.4$ & $11.1 \pm 0.7$ \\
\hline C. jacquemontii & $42.7 \pm 9.3$ & $3.2 \pm 0.6$ & $20.7 \pm 0.8$ \\
\hline I. dipyrena & 6.4 & 0.6 & 4.1 \\
\hline L. umbrosa & $69.1 \pm 6.8$ & $1.1 \pm 0.2$ & $28.1 \pm 3.1$ \\
\hline L. ovalifolia & 9.1 & 1.5 & 5.6 \\
\hline M. esculenta & $12.7 \pm 0.1$ & $1.0 \pm 0.1$ & $7.4 \pm 2.3$ \\
\hline Q. floribunda & $107.3 \pm 8.0$ & $20.9 \pm 1.9$ & $81.9 \pm 5.9$ \\
\hline Q. leucotrichophora & 5.5 & 0.5 & 3.8 \\
\hline R. arboreum & $49.1 \pm 3.3$ & $1.7 \pm 0.1$ & $22.9 \pm 4.3$ \\
\hline S. chinensis & 8.2 & 0.7 & 3.6 \\
\hline Others & $34.5 \pm 11.4$ & $2.7 \pm 0.5$ & $27.7 \pm 6.7$ \\
\hline Total & 490.0 & 53.0 & \\
\hline \multicolumn{4}{|c|}{ Mixed oak forest } \\
\hline A. pictum & $70.0 \pm 4.1$ & $11.8 \pm 3.6$ & $41.8 \pm 22.4$ \\
\hline Aesculus indica & 23.3 & 6.0 & 16.4 \\
\hline Juglans regia & 33.3 & 2.7 & 12.8 \\
\hline Q. floribunda & $83.3 \pm 8.8$ & $19.4 \pm 3.2$ & $63.3 \pm 6.3$ \\
\hline Q. semecarpifolia & $90.0 \pm 10.0$ & $22.8 \pm 2.8$ & $71.7 \pm 9.6$ \\
\hline R. arboreum & $66.7 \pm 0.1$ & $2.0 \pm 1.6$ & $29.6 \pm 11.1$ \\
\hline Taxus wallichiana & $60.0 \pm 16.3$ & $5.2 \pm 1.0$ & $36.7 \pm 4.9$ \\
\hline Others & $56.7 \pm 12.2$ & $3.3 \pm 0.4$ & $27.4 \pm 8.6$ \\
\hline Total & 483.3 & 73.2 & \\
\hline \multicolumn{4}{|c|}{ Kharsu oak mixed forest } \\
\hline Acer pictum & 20.0 & 4.2 & 16.2 \\
\hline A. indica & 20.0 & 3.6 & 14.4 \\
\hline Betula utilis & 12.0 & 0.5 & 5.4 \\
\hline C. jacquemontii & $62.0 \pm 7.6$ & $5.2 \pm 0.4$ & $36.8 \pm 5.1$ \\
\hline Juglans regia & $94.0 \pm 25.7$ & $11.1 \pm 6.6$ & $46.9 \pm 10.7$ \\
\hline Q. semecarpifolia & $112.0 \pm 9.7$ & $29.6 \pm 4.9$ & $90.5 \pm 5.5$ \\
\hline R. arboreum & $106.0 \pm 14.7$ & $3.7 \pm 1.5$ & $47.2 \pm 3.7$ \\
\hline Taxus wallichiana & $44.0 \pm 0.1$ & $2.6 \pm 0.7$ & $22.3 \pm 4.8$ \\
\hline Others & $38.0 \pm 9.5$ & $2.6 \pm 0.6$ & $20.2 \pm 6.9$ \\
\hline Total & 508.0 & 63.0 & \\
\hline
\end{tabular}

was 432 individuals $\mathrm{ha}^{-1}$, of which Litsea umbrosa contributed $43 \%$ and the total tree seedling density was 582 individuals ha ${ }^{-1}$, of which $A$. pictum contributed $31 \%$ and followed by Q. floribunda (21\%; Tab. 2). The total shrub
Tab. 1. Density, Total Basal Area (TBA) and Importance Value Index (IVI) of different species in different forest communities (cont.)

\begin{tabular}{|c|c|c|c|}
\hline Species & $\begin{array}{c}\text { Density } \\
\left(\text { trees ha }^{-1}\right)\end{array}$ & $\begin{array}{c}\text { TBA } \\
\left(\mathrm{m}^{2} \mathrm{ha}^{-1}\right)\end{array}$ & IVI \\
\hline \multicolumn{4}{|c|}{ Kharsu oak forest } \\
\hline C. jacquemontii & 10.0 & 0.8 & 7.5 \\
\hline J. regia & $94.0 \pm 18.6$ & $5.8 \pm 0.9$ & $47.2 \pm 2.8$ \\
\hline L. umbrosa & 24.0 & 0.2 & 10.8 \\
\hline Q. floribunda & 10.0 & 2.4 & 13.8 \\
\hline Q. semecarpifolia & $122.0 \pm 26.2$ & $35.4 \pm 7.0$ & $116.9 \pm 7.8$ \\
\hline R. arboreum & 16.0 & 0.6 & 15.7 \\
\hline R. campanulatum & $62.0 \pm 9.5$ & $3.1 \pm 0.5$ & $28.4 \pm 5.9$ \\
\hline T. wallichiana & $52.0 \pm 18.1$ & $4.7 \pm 0.7$ & $39.6 \pm 6.3$ \\
\hline Others & $74.0 \pm 22.1$ & $5.7 \pm 2.3$ & $20.2 \pm 14.5$ \\
\hline Total & 464.0 & 58.7 & \\
\hline \multicolumn{4}{|c|}{ Walnut - mixed forest } \\
\hline R. arboreum & 100.0 & 3.0 & 59.4 \\
\hline J. regia & 110.0 & 13.2 & 104.8 \\
\hline T. wallichiana & 100.0 & 7.0 & 77.8 \\
\hline L.umbrosa & 100.0 & 2.0 & 57.9 \\
\hline Total & 410.0 & 25.2 & \\
\hline \multicolumn{4}{|c|}{ Kharsu oak - yew forest } \\
\hline Q. semecarpifolia & $100.0 \pm 6.3$ & $32.9 \pm 0.5$ & $173.7 \pm 5.0$ \\
\hline R. arboreum & 12.5 & 0.4 & 11.1 \\
\hline T. wallichiana & $97.5 \pm 6.3$ & $8.2 \pm 0.5$ & $115.2 \pm 5.0$ \\
\hline Total & 210.0 & 41.4 & \\
\hline \multicolumn{4}{|c|}{ Kharsu oak - birch forest } \\
\hline B. utilis & $103.3 \pm 3.3$ & $14.0 \pm 4.5$ & $132.2 \pm 6.6$ \\
\hline Q. semecarpifolia & $100.0 \pm 0.1$ & $28.7 \pm 0.3$ & $167.8 \pm 6.5$ \\
\hline Total & 203.3 & 42.6 & \\
\hline
\end{tabular}

density was 9604 individuals ha $^{-1}$ and the total herb density was 36 individuals $\mathrm{m}^{-2}$.

\section{Mixed oak forest}

The total tree density of the forest was 483 trees ha ${ }^{-1}$, of which 19,17 and $14 \%$ contributed by Q. semecarpifolia, Q. floribunda and A. pictum, respectively (Tab. 1). The total basal area was $73.2 \mathrm{~m}^{2} \mathrm{ha}^{-1}$, of which $31 \%$ and $27 \%$ contributed by Q. semecarpifolia and Q.floribunda, respectively. The dominant tree species of the forest were Q. semecarpifolia and Q. floribunda with IVI values 72 and 63, respectively. The snag density of the forest was $27 \pm 13.5$ trees ha ${ }^{-1}$. The total tree sapling density was 395 individuals $\mathrm{ha}^{-1}$ and T. wallichiana contributed the maximum (42\%). The total tree seedling density was 2053 individuals ha- ${ }^{-1}$, of which T. wallichiana contributed $44 \%$. The total shrub density was 4307 individuals ha ${ }^{-1}$ and Indigofera and Cotoneaster contributed the maximum (25\% each; Tab. 2). The total herb density was 44 individuals $\mathrm{m}^{-2}$, of which Bergenia contributed $14 \%$.

\section{Kharsu oak-mixed forest}

The total tree density of the forest was 508 trees ha $^{-1}$, of which $22 \%$ contributed by Q. semecarpifolia and fol- 
50

Tab. 2. Density of sapling and seedling of tree (individuals ha ${ }^{-1}$ ), shrubs (individuals $\mathrm{ha}^{-1}$ ) and herbs (individuals $\mathrm{m}^{-2}$ )

\begin{tabular}{cccccc}
\hline \multirow{2}{*}{ Forest/Community } & \multicolumn{5}{c}{ Density } \\
\cline { 2 - 6 } & Seedling & Sapling & Tree & Shrub & Herb \\
\hline Alder mixed forest & 1047.0 & 13.3 & 343.0 & 4760.0 & 24.2 \\
Tilonj oak - mixed forest & 581.8 & 432.0 & 490.0 & 9603.6 & 35.8 \\
\hline Mixed oak forest & 2053.0 & 646.7 & 483.0 & 4306.7 & 44.1 \\
Kharsu oak mixed forest & 832.0 & 314.0 & 508.0 & 6024.0 & 25.0 \\
\hline Kharsu oak forest & 2584.0 & 550.0 & 464.0 & 8344.0 & 39.5 \\
Walnut - mixed forest & 2080.0 & 1360.0 & 410.0 & 7240.0 & 65.0 \\
Kharsu oak - Yew forest & 1870.0 & 660.0 & 210.0 & 7450.0 & 42.6 \\
Kharsu oak - Birch forest & 333.3 & 470.0 & 203.0 & 10240.0 & 31.1 \\
\hline Berberis community & - & - & - & 2680.0 & 31.3 \\
Bamboo community & - & - & - & 5900.0 & 42.6 \\
\hline
\end{tabular}

lowed by $R$. arboreum (21\%; Tab. 1). The total basal area was $63.0 \mathrm{~m}^{2} \mathrm{ha}^{-1}$, of which Q. semecarpifolia contributed $47 \%$. The dominant tree species was Q. semecarpifolia and had maximum IVI (91). The snag density of the forest was $42 \pm 18$ trees ha ${ }^{-1}$. The total tree sapling density was 328 individuals ha ${ }^{-1}$, of which $46 \%$ contributed by Q. semecarpifolia. The total tree seedling density was 832 individuals ha ${ }^{-1}$, of which $30 \%$ contributed by J. regia and $28 \%$ by $Q$. semecarpifolia (Tab. 2). The total shrub density was 6024 individuals ha ${ }^{-1}$, of which Chimnobambusa falcata contributed $36 \%$. The total herb density was 25 individuals $\mathrm{m}^{-2}$ and maximum contribution was $20 \%$ by Thymus serpyllum.

\section{Kharsu oak forest}

The total tree density of the forest was 464 trees ha- ${ }^{-1}$, of which $26 \%$ contributed by Q. semecarpifolia. The total basal area was $58.7 \mathrm{~m}^{2} \mathrm{ha}^{-1}$ and Q. semecarpifolia contributed $60 \%$ (Tab. 1). The dominant tree species was Q. semecarpifolia with maximum IVI (117). The snag density of the forest was $30 \pm 21$ trees ha-1. The total tree sapling density was 513 individuals ha ${ }^{-1}$, of which $47 \%$ contributed by Q. semecarpifolia and followed by J. regia (39\%). The total tree seedling density was 2584 individuals ha ${ }^{-1}$, of which J. regia contributed $40 \%$ followed by $Q$. semecarpifolia
(31\%) and T. wallichiana (29\%). The total shrub density was 3906 individuals ha-1 ${ }^{-1}$ of which Chimnobambusa falcata contributed $83 \%$ (Tab. 2). The total herb density was 39 individuals $\mathrm{m}^{-2}$ and dominated by Potentilla and Iris (10\% each).

\section{Walnut-mixed forest}

The total tree density of the forest was 410 trees ha $^{-1}$ and all the species contributed equally to the density. The total basal area was $25.2 \mathrm{~m}^{2}$ ha ${ }^{-1}$, of which $52 \%$ contributed by $J$. regia (Tab. 1). The dominant tree species was Juglans regia with maximum IVI (105). The snags were totally absent in the forest. The total tree sapling density was 1360 individuals ha ${ }^{-1}$, of which Litsea umbrosa occupied $60 \%$ (Tab. 2). The total tree seedling density was 2080 individuals ha ${ }^{-1}$ and Juglans regia contributed $77 \%$. The total shrub density was 7240 individuals ha ${ }^{-1}$, of which Cannabis sativa contributed $36 \%$ followed by Chimnobambusa falcata (29\%). The total herb density was 59 individuals $\mathrm{m}^{-2}$ and dominated by Potentilla fulgens (24\%; Tab. 2).

\section{Kharsu oak-Yew forest}

The total tree density of the forest was 210 trees ha ${ }^{-1}$, of which $48 \%$ contributed by Q. semecarpifolia and followed by Taxus wallichiana (46\%). The total basal area was 41.4 $\mathrm{m}^{2} \mathrm{ha}^{-1}$ and Q. semecarpifolia contributed $79 \%$. The dominant tree species was Q. semecarpifolia with maximum IVI (174; Tab. 1). The snag density of the forest was $93 \pm 11$ trees $\mathrm{ha}^{-1}$. The total tree sapling density was 752 individuals ha ${ }^{-1}$, of which $40 \%$ and $32 \%$ contributed by Taxus wallichiana and $Q$. semecarpifolia, respectively. The total tree seedling density of the forest was 1870 individuals ha-1, of which Taxus wallichiana contributed $75 \%$. The total shrub density was 7450 individuals $\mathrm{ha}^{-1}$ and dominated by Cotoneaster (28\%; Tab. 2). The total herb density of the forest was 43 individuals $\mathrm{m}^{-2}$ and dominanted by Iris kumaonensis (32\%).

\section{Kharsu oak-Birch forest}

The tree density of kharsu oak-birch forest was 203 trees ha $^{-1}$, of which Betula utilis contributed $51 \%$ followed by $Q$.

Tab. 3. Species richness (SR), diversity (H') and evenness (E) of tree, shrub and herb layers in different forests/communities

\begin{tabular}{ccccccccccc}
\hline \multirow{2}{*}{ Forest/Community } & \multicolumn{3}{c}{ Tree } & \multicolumn{3}{c}{ Shrub } & \multicolumn{3}{c}{ Herb } \\
\cline { 2 - 10 } & SR & H' & E & SR & H' & E & SR & $H^{\prime}$ & E \\
\hline Alder mixed forest & 9 & 1.909 & 0.75 & 11 & 2.035 & 0.696 & 15 & 2.953 & 1.278 \\
Tilonj oak - mixed forest & 7 & 1.826 & 0.887 & 18 & 2.683 & 0.813 & 20 & 3.53 & 1.705 \\
Mixed oak forest & 7 & 1.875 & 0.931 & 6 & 1.712 & 0.924 & 14 & 2.768 & 1.138 \\
Kharsu oak mixed forest & 7 & 1.841 & 0.901 & 9 & 1.921 & 0.758 & 11 & 2.47 & 1.075 \\
\hline Kharsu oak forest & 5 & 1.544 & 0.936 & 11 & 2.252 & 0.865 & 16 & 3.005 & 1.261 \\
Walnut - mixed forest & 4 & 1.385 & 0.999 & 4 & 1.336 & 0.951 & 10 & 2.165 & 0.871 \\
\hline Kharsu oak - Yew forest & 3 & 0.877 & 0.801 & 6 & 1.699 & 0.911 & 8 & 2.04 & 0.961 \\
Kharsu oak - Birch forest & 2 & 0.693 & 0.999 & 4 & 1.292 & 0.91 & 6 & 1.745 & 0.955 \\
\hline Berberis community & - & - & - & 4 & 0.834 & 0.576 & 4 & 1.239 & 0.863 \\
Bamboo community & - & - & - & 1 & - & - & 6 & 1.715 & 0.926 \\
\hline
\end{tabular}


semecarpifolia (49\%) and the total basal area was $42.6 \mathrm{~m}^{2}$ $\mathrm{ha}^{-1}$, of which $67 \%$ contributed by Q. semecarpifolia (Tab. $1)$. The dominant tree species was $Q$. semecarpifolia with maximum IVI (168). The snag density of the forest was $63 \pm 35$ trees $\mathrm{ha}^{-1}$. The total tree sapling density was 313 individuals $\mathrm{ha}^{-1}$ and the contribution of $Q$. semecarpifolia was maximum (65\%). The total seedling density was 333 individuals $\mathrm{ha}^{-1}$ and dominated only by $Q$. semecarpifolia (Tab. 2). The total shrub density was 10240 individuals ha $^{-1}$ and dominated by Juniper macropoda and Skimmia laureola (39 and 30\%, respectively). The total herb density of the forest was 31 individuals $\mathrm{m}^{-2}$ and Morina and Iris contributed the maximum (26\% each).

\section{Berberis community}

The total shrub density of the community was 2440 individuals ha ${ }^{-1}$, of which Berberis chitria contributed $79 \%$ (Tab. 2). The total herb density of the community was 20 individuals $\mathrm{m}^{-2}$ and Oxalis corniculata was the dominant species (44\%).

\section{Bamboo community}

The total shrub density of bamboo community was 5900 individuals ha ${ }^{-1}$ (Tab. 2) and Chimnobambusa falcata is the only species.

Among different forest communities the highest density of trees recorded for kharsu oak-mixed forest, tilonj oak-mixed forest and mixed oak forest (483-508 trees ha ${ }^{1}$ ), sapling density for Walnut-mixed forest (1360 sapling ha $^{-1}$ ), seedling density for kharsu oak forest (2584 seedling $\mathrm{ha}^{-1}$ ), shrub density for kharsu oak-birch forest and Tilonj oak-mixed forest (9604-10240 shrubs ha ${ }^{-1}$ ) and herb density for Walnut-mixed forest (65 individuals $\mathrm{m}^{-2} ;$ Tab. 2).

\section{Species richness and diversity}

The tree species richness was highest in alder mixed forest (9) followed by tilonj oak-mixed forest, mixed oak forest and kharsu oak mixed forest ( 7 in each), while lowest species richness was in kharsu oak-birch forest (2; Tab. 3). The tree diversity ranged from 0.693 (kharsu oak-birch forest) to 1.909 (alder mixed forest, Tab. 3). The shrub species richness was highest in tilonj oak-mixed forest (18) and lowest in bamboo community (1). The shrub diversity was highest in tilonj oak-mixed forest (2.683) followed by alder mixed forest (2.035) and lowest in Berberis community $(0.834$, Tab. 3). The herb species richness was highest in tilonj oak-mixed forest (20) followed by kharsu oak forest (16) and alder-mixed forest (15) and lowest in Berberis community (4). The distribution pattern of trees, shrubs and herbs shows that species were evenly distributed in most of the sites (Tab. 3).

The $\beta$ diversity, a measure of rate of species change was observed and it was in following order: tilonj oak-mixed forest (3.9) $>$ kharsu oak forest $(2.8)>$ alder mixed forest (2.5) $>$ kharsu oak mixed forest $(1.8)>$ mixed forest $(1.7)$ $>$ kharsu oak-yew forest $(1.3)>$ walnut-mixed forest, khar- su oak forest and birch forest (1.0). However, the zonal $\beta$ diversity was highest in upper temperate (5.9) followed by sub-alpine (4.0) and lower temperate (1.9). The $\beta$ diversity for the entire Chenab valley $(1750-3060 \mathrm{~m})$ was 7.4 .

\section{Discussion}

The alder forest seems to be an early seral stage along riverine areas (Mohan and Puri, 1954), however, silver fir with some broadleaved species seems to be a late seral stage in one of the forest of the present study area in the higher altitudes, appearing as the climax and similar association is also suggested (Parker, 1942). This is mainly due to the fact that these areas become nitrogen depleted and alder is the only species to grow along riverine areas and establish themselves due to their ability to fix nitrogen (Sharma and Ambasht, 1988). In the present study, the density of alder forest is 4-5 times lower than the values reported for Pindari region, Kumaun (Adhikari et al., 1991). The density values of tilonj oak-mixed forests of present study area ranged from 350-720 trees ha ${ }^{-1}$, which are on the higher side of the values reported for Dharamganga, Asiganga, Bhatwari and Dogadda watersheds (240-370 trees ha- $\left.{ }^{-1}\right)$ by Adhikari and Rawat (2004), however, the values (7601107 trees ha $^{-1}$ ) reported for Kumaun region by Singh et al. (1994) are higher than the reported values of present study. The density values of kharsu oak dominated forest in present study ranged from 264-545 trees ha ${ }^{-1}$, which is higher than that of reported for kharsu oak by Adhikari and Rawat (2004) in Bhatwari and Asiganga watersheds (223 and 230 trees ha $^{-1}$, respectively). The density values reported for Dharamganga (362 trees ha ${ }^{-1}$ ) and Dogadda ( 372 trees ha $^{-1}$ ) catchments by Adhikari and Rawat (2004), timberline kharsu oak forest $\left(340\right.$ trees ha $\left.{ }^{-1}\right)$ in Tungnath by Rai et al. (2012),) and for Pindar catchment (480 trees ha $^{-1}$ ) by Adhikari et al. (1995) are comparable with the present study forests and lower than that of the values reported for Tungnath by Rai et al. (2012) at subalpine region (810 trees ha $\left.{ }^{-1}\right)$.

The density values of mixed broadleaved forest in Pindari region of Kumaun (360-640 trees ha ${ }^{-1}$ ) reported by Adhikari et al. (1991) are higher than that of the present study and comparable with conifer-broadleaved forest (413 trees ha ${ }^{-1}$ ) of Sakteng WS (Adhikari, 2005). The density values of kharsu oak-birch forest $\left(203\right.$ trees ha $\left.^{-1}\right)$ of present study is comparable with the values (205 trees ha ${ }^{-1}$ and 238-250 trees ha ${ }^{-1}$, respectively) reported for Gangotri region by Adhikari and Rawat (2004) and Nanda Devi National Park by Adhikari (2004). However, the density value of birch forest (700 trees ha $\left.{ }^{-1}\right)$ in Pindar catchment, Kumaun by Garkoti and Singh (1994) and in Sakteng WS, Bhutan (573 trees ha ${ }^{-1}$ ) by Adhikari (2005) are on the higher side of the range reported for present study. The density values reported by Adhikari (2005) in Sakteng Wildlife Sanctuary for oak-conifer forest (144 trees ha- $\left.{ }^{-1}\right)$ and oak forest $\left(270\right.$ trees ha $\left.{ }^{-1}\right)$ are on the lower side of the 
52

Tab. 4. Comparative account of tree density $\left(\right.$ tree ha $\left.{ }^{-1}\right)$ and total basal area $\left(\mathrm{m}^{2} \mathrm{ha}^{-1}\right)$ from different study sites in west Himalayan region

\begin{tabular}{|c|c|c|c|}
\hline Forest type & Tree density & Total basal area & Reference \\
\hline \multirow{3}{*}{ P. roxburghii } & $540-1630$ & $25.0-47.2$ & Singh et al. (1994) \\
\hline & 335 & 46.3 & Adhikari and Rawat (2004) \\
\hline & 616 & 43.9 & Dhar et al. (1997) \\
\hline \multirow{3}{*}{ Q. leucotrichophora } & 570 & 36.8 & Singh et al. (1994) \\
\hline & 295.0 & 23.5 & Adhikari and Rawat (2004) \\
\hline & 1100 & 35.3 & Dhar et al. (1997) \\
\hline \multirow{2}{*}{ Quercus floribunda } & $760-1107$ & $33.9-71.0$ & Singh et al. (1994) \\
\hline & 298 & 56.2 & Adhikari and Rawat (2004) \\
\hline \multirow{2}{*}{ Aesculus indica } & 280 & 59.7 & Singh et al. (1994) \\
\hline & 330 & 74.5 & Adhikari and Rawat (2004) \\
\hline Cupressus torulosa & $270-510$ & $26.6-51.5$ & Adhikari et al. (1998) \\
\hline Cedrus deodara & 370 & 24.8 & Adhikari and Rawat (2004) \\
\hline P. wallichiana-C. deodara & 865 & 59.9 & Kumar et al. (1997) \\
\hline \multirow{2}{*}{ Quercus lanuginosa } & $660-993$ & $35.8-60.0$ & Singh et al. (1994) \\
\hline & 832 & 67.7 & Dhar et al. (1997) \\
\hline \multirow{4}{*}{ Abiespindrow } & 350 & 105.6 & Singh et al. (1994) \\
\hline & 260 & 30.4 & Adhikari and Rawat (2004) \\
\hline & $258-322$ & $28.9-48.7$ & Adhikari (2004) \\
\hline & 660 & 78.9 & Dhar et al. (1997) \\
\hline Abies densa & 298 & 27.1 & Adhikari (2005) \\
\hline \multirow{4}{*}{ Quercus semecarpifolia } & 480 & 73.0 & Singh et al. (1994) \\
\hline & 304 & 38.8 & Adhikari and Rawat (2004) \\
\hline & 550 & 50.8 & Dhar et al. (1997) \\
\hline & $340-810$ & $30-65.2$ & Rai et al. (2012) \\
\hline Acer cappadocicum & 505 & 56.3 & Garkoti and Singh (1994) \\
\hline Abiespindrow-B. utilis & 230 & 36.9 & Adhikari (2004) \\
\hline \multirow{6}{*}{ B. utilis-R. campanulatum } & 700 & 28.3 & Garkoti and Singh (1994) \\
\hline & 205 & 5.2 & Adhikari and Rawat (2004) \\
\hline & 573 & 28.4 & Adhikari (2005) \\
\hline & $238-250$ & $12.7-16.2$ & Adhikari (2004) \\
\hline & 470 & 21.4 & Dhar et al. (1997) \\
\hline & $420-780$ & $6.4-28.5$ & Rai et al. (2012) \\
\hline \multirow{2}{*}{ R. campanulatum } & 196 & 8.6 & Adhikari (2005) \\
\hline & 1180 & 11.7 & Garkoti and Singh (1994) \\
\hline
\end{tabular}

range reported for the present study. The density values reported for $P$. wallichiana - C. deodara and A. spectabilis- $Q$. semecarpifolia forests (2100 trees ha-1 and 2090 tree ha ${ }^{-1}$, respectively) by Kunwar and Sharma (2004) are quite higher than the values reported for present study.

The total density of shrubs in present study forests ranged from 1960 (alder mixed forest) - 23120 shrubs $\mathrm{ha}^{-1}$ (kharsu oak forest). The shrub density of all the forests of present study is more or less similar, except tilonj oak-mixed forest, kharsu oak forest and kharsu oak-birch forest, where upper limit of density is too high. These values are comparable with the range reported for mixedbroadleaved forest and silver fir-tilonj oak mixed broadleaved forest (1880-6090 shrubs ha ${ }^{-1}$ and 6630 shrubs ha $^{-1}$, respectively) by Adhikari et al. (1991) and cypress forest (1280-4170 shrubs ha' ${ }^{-1}$ ) by Adhikari et al. (1998). The shrub density values reported by Adhikari (2005) for oakconifer forest and conifer-broadleaved forest (6497 and 6661 shrubs ha $^{-1}$, respectively) of Sakteng WS, Bhutan are also comparable with the present study forests, while the values of oak forest (1496 shrubs ha ${ }^{-1}$ ) are on the lower side of the range reported for present study forests. A comparative account of density is given in Tab. 4 .

The total basal area in alder mixed forest of present study area ranged from 14-34 $\mathrm{m}^{2} \mathrm{ha}^{-1}$, which is quite lower than the basal area reported for alder forest in Pindar catchment, Kumaun Himalaya (Adhikari et al., 1991). The total basal area of tilonj oak-mixed forest in the present study ranged from $40-70 \mathrm{~m}^{2} \mathrm{ha}^{-1}$, which is comparable with the total basal area reported for tilonj oak forest in Dharamganga, Bhatwari and Dogadda watersheds $\left(49-65 \mathrm{~m}^{2} \mathrm{ha}^{-1}\right)$ by Adhikari and Rawat (2004) and also comparable with 
the range reported for Kumaun Himalaya $\left(34-71 \mathrm{~m}^{2} \mathrm{ha}^{-1}\right)$ by Singh et al. (1994). However, the total basal area values for tilonj oak-mixed forest reported by Adhikari and Rawat (2004) in Dharamganga and Asiganga watersheds (34$36 \mathrm{~m}^{2} \mathrm{ha}^{-1}$ ) are lower than that of present study forest.

The total basal area of kharsu oak forest in the present study ranged from $42-78 \mathrm{~m}^{2} \mathrm{ha}^{-1}$, which is higher than that reported by Adhikari and Rawat (2004) for Dharnmaganga, Bhatwari, Asiganga and Dogadda watersheds (40, 41, 36 and $36 \mathrm{~m}^{2} \mathrm{ha}^{-1}$, respectively), however, comparable with the values reported by Adhikari et al. (1995) for kharsu oak forest in Pindar catchment, Kumaun Himalaya $\left(76 \mathrm{~m}^{2}\right.$ $\mathrm{ha}^{-1}$ ) and subalpine kharsu oak forest by Rai et al. (2012) in Tungnath $\left(65.2 \mathrm{~m}^{2} \mathrm{ha}^{-1}\right)$. The total basal area of kharsu oakbirch forest is on the higher side of the range reported for present study forest than that of birch forest by Adhikari (2004) in Nanda Devi NP (13-16 $\left.\mathrm{m}^{2} \mathrm{ha}^{-1}\right)$, Adhikari and Rawat (2004) in Gangotri watershed $\left(5 \mathrm{~m}^{2} \mathrm{ha}^{-1}\right)$ and Singh et al. (1994) in Pindar catchment, Kumaun Himalaya (23 $\left.\mathrm{m}^{2} \mathrm{ha}^{-1}\right)$, as these are pure birch forests. The total basal area values of present study forests ranged from $18-72 \mathrm{~m}^{2} \mathrm{ha}^{-1}$ are comparable with the values reported for the forests of Kumaun Himalaya (23-61 $\left.\mathrm{m}^{2} \mathrm{ha}^{-1}\right)$ by Rikhari et al. (1991) and 21-84 $\mathrm{m}^{2} \mathrm{ha}^{-1}$ for tropical and temperate forests of the world by several workers (Dabel and Day, 1977; Duvugneaud and Denaeyer De-Smet, 1970; Franklin et al., 1979; Reiners, 1972; Rochow, 1972). Similarily, the total basal area reported by Bhandari et al. (1997) for temperate forests of Garhwal Himalaya $\left(15-60 \mathrm{~m}^{2} \mathrm{ha}^{-1}\right)$ is comparable with the present study forests, while the density (320-2080 trees $\left.\mathrm{ha}^{-1}\right)$ is quite higher than that reported for present study $\left(203-545\right.$ tees ha $\left.{ }^{-1}\right)$. The total basal area values for $P$.

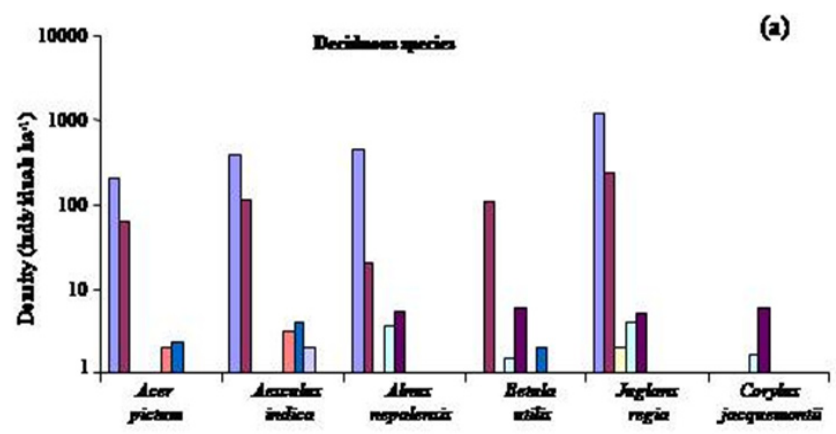

(a)

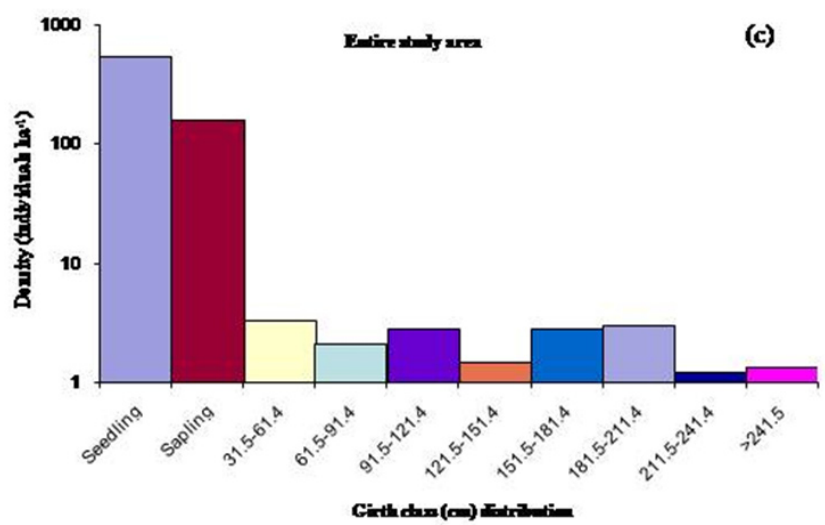

Fig. 3. Population structure of different deciduous (a) and evergreen (b) species and pattern of regeneration in the entire study area
wallichiana-C. deodara and A. spectabilis-Q. semecarpifolia forests $\left(90 \mathrm{~m}^{2} \mathrm{ha}^{-1}\right.$ and $152 \mathrm{~m}^{2} \mathrm{ha}^{-1}$, respectively) reported by Kunwar and Sharma (2004) are quite higher than that reported for present study. A comparative account of total basal area of different forests is given in Tab. 4 .

The polynomial regression shows that the density of trees decline $\left(\mathrm{r}^{2}=0.52, p<0.001\right)$ along an altitudinal gradient (Fig. 3a), while there is no correlation between altitude with density of shrubs and herbs. No correlation was observed between the density of trees, shrubs and herbs. The polynomial regression shows that the total basal area of trees decline $\left(r^{2}=0.24, p<0.01\right)$ along an altitudinal gradient (Fig. 3b). A significant positive correlation $\left(\mathrm{r}^{2}=\right.$ $0.46, p<0.001$ ) was observed between the total basal area and density (Fig. 3c). Similar observations were also made for the forests of Kumaun Himalaya (Adhikari et al., 1991; Rikhari et al., 1997; Singh et al., 1994).

The tree species diversity values (0.69-1.91) of present study forests lie on the lower side of the range reported by several workers (Monk, 1967; Ralhan et al., 1982; Risser and Rice, 1971; Saxena and Singh, 1982) for temperate forests (0.8-3.4) and are less than those reported for moist tropical forests (3.5-5.4) by Knight (1975) and Singh et al. (1981). The diversity values are compared with the values reported for high altitude forests by Adhikari et al. (1991) and Dhar et al. (1997) in Pindar catchment (0.81-3.55) and Askot WS (0.68-2.39), respectively in Kumaun Himalaya and Adhikari (2005) for various forest communities in Sakteng WS, Bhutan (0.19-1.78).

As it is reflected by the $\beta$ diversity values that these forests form the lower and upper transition zones in the present study area, are comparable with the values reported

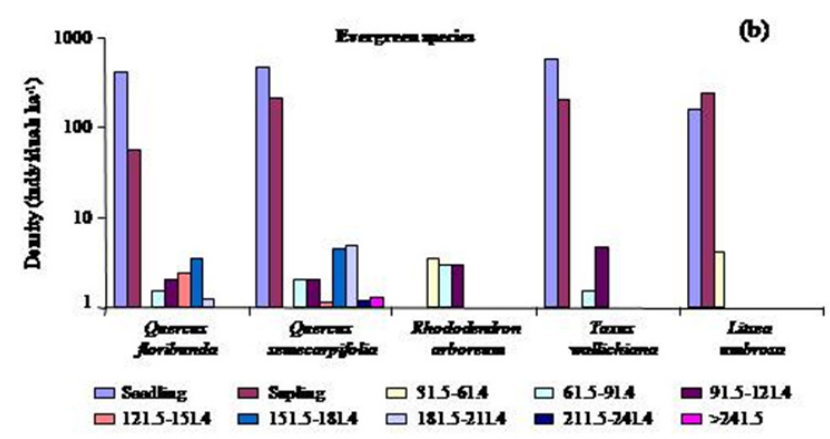

(c) 
54

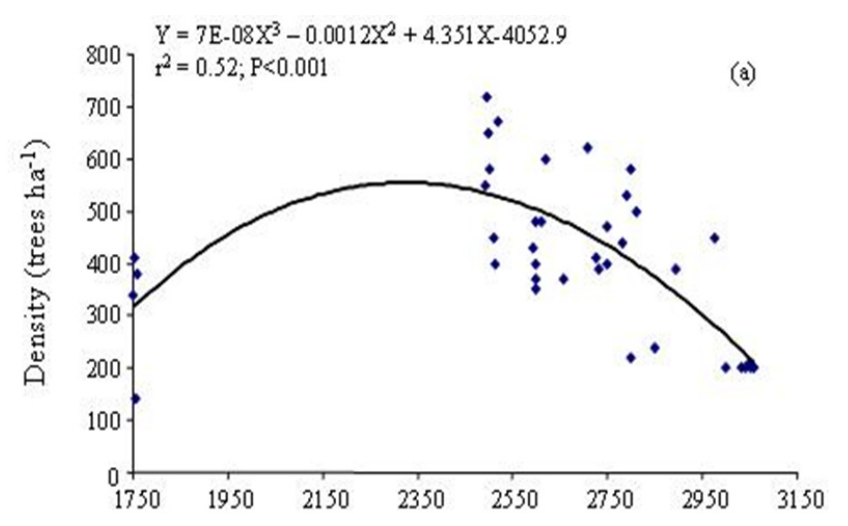

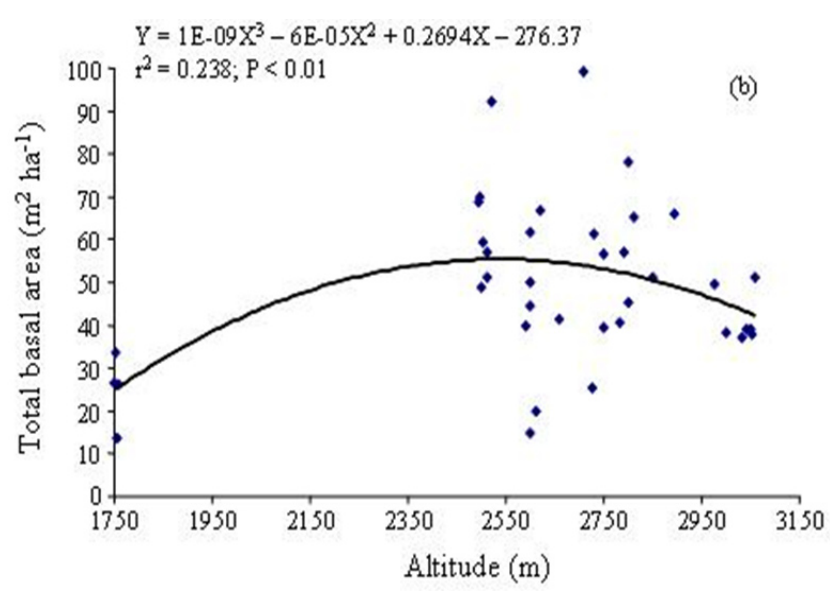

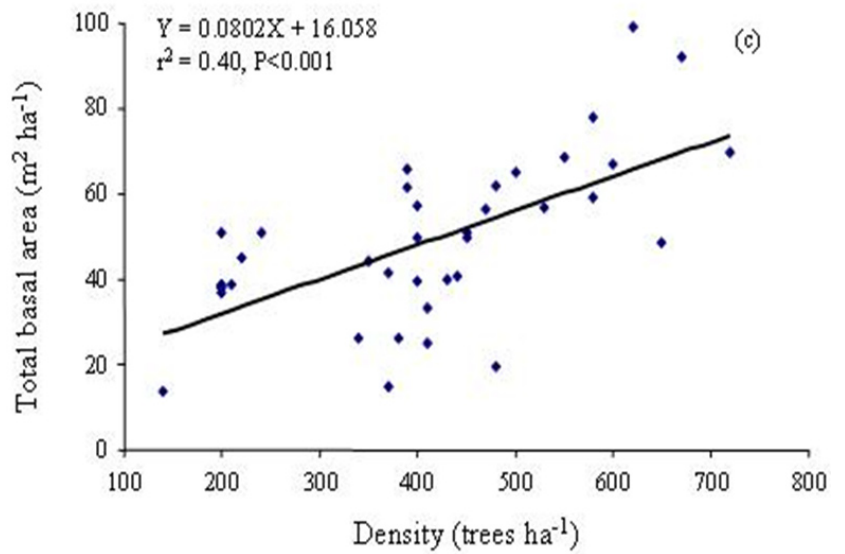

Fig. 4. Relationships between density, total basal area with altitude and total basal area with density in the study area

for Bhagirathi catchment (upper temperate: 4.1 and subalpine: 4.5), while too low for warm temperate zone: 3.9 (Adhikari 1997). The $\beta$ diversity values of present study forests are also well within the range ( $<2000: 2.6$, between 2000-2500: 3.1 and between 2500-3000: 5.5; except $>3000 \mathrm{~m}: 10.0)$ reported along an altitudinal gradient in Sakteng WS (Adhikari, 2005). The high $\beta$-diversity value in the sub-alpine zone is mainly due to different communities of kharsu oak and also reported for the Sakeng WS in sub-alpine zone that the topography supports the growth of various forest communities. The $\beta$ diversity values of present study forests are comparable with the values (1.2-2.1) reported for the forests along an altitudinal gradient at and around Nainital by Rikhari et al. (1991), and across the gradient of disturbance in oak forests (undisturbed forests: 0.5 and disturbed forests: 2.9) by Upreti et al. (1985). The overall $\beta$-diversity of the study area is 7.3, which is within the range reported for Nepal $(4.8-20.6)$ by several workers (Kanai et al., 1975; Ohsawa et al., 1975; Schmidt-Vogt, 1990; Yoda, 1967) and lower than that of Kumaun Himalaya (14.5) reported by Singh et al. (1994).

\section{Conclusions}

In nutshell, the seedlings and saplings of Betula utilis and Q. semecarpifolia in their own forest have shown good regeneration, while Abies pindrow and Cedrus deodara proliferated in the area. The broken branches of Taxus due to heavy snowfall have led the formation of canopy gaps, which has supported bamboo growth. The alpine meadows above timberline are reservoir of many ecologically and economically (medicinal) important species, which needs adequate research and management. The impact of climatic variability can be seen by the invasion of Betula utilis and Juniperus macropoda in the meadows. The meadows like Selamghetta, Darkharak and Pilpar have added aesthetic value to the valley and showed a drastic change in plant communities and their composition. Due to heavy anthropogenic pressure in these meadows and nearby forests, which has led the habitat destruction, imposed a threat to the endangered plant species as well as the wildlife of the area. Therefore, it is felt that the livestock grazing can be controlled through the regulatory mechanism i.e. rotational grazing, as it has been a major pressure in the past, to conserve the biodiversity and sustainability of the area with the help of State Forest Department.

\section{Acknowledgement}

The authors are thankful to the Director and Dean, Wildlife Institute of India, Dehradun for providing necessary facilities. The authors thank Shri A.K. Banerjee, DFO, Nanda Devi Biosphere Reserve for providing help and cooperation during the course of study. 


\section{References}

Adhikari BS (2004). Ecological attributes of vegetation in and around Nanda Devi National Park, 15-38 p. In: Biodiversity Monitoring Expedition Nanda Devi 2003, Govt of India, New Delhi and Uttaranchal Forest Department.

Adhikari BS (2005). Floral Characteristics and Vegetation Patterns in Sakteng Wildlife Sanctuary, Bhutan, 11-84 p. In: Wildlife Institute of India, Dehradun to WWF-Bhutan and Nature Conservation Division, Royal Government of Bhutan. Vegetation, Bird and Mammal Surveys in Sakteng Wildlife Sanctuary, Bhutan.

Adhikari BS, Dhaila-Adhikari S, Rawat YS (1998). Structure of Himalayan moist temperate cypress forest at and around Nainital, Kumaun Himalayas. Oecol Mont 7:21-31.

Adhikari BS, Rawat GS (2004). Assessment of Garhwal Himalayan forests with special reference to climate change, 115-125 p. In: Ravindranath NH, Sharma SK, Garg A, Bhattacharya S, Murthy IK (Eds.). Proc of the Workshop on Vulnerability Assessment and Adaptation due to Climate Change on Indian Agriculture, Forestry and Natural Ecosystems. Indian Inst Sci, Bangalore, MoEF, Govt of India, New Delhi.

Adhikari BS, Rawat YS, Singh SP (1995). Structure and function of high altitude forests of central Himalaya, I. Dry matter dynamics. Ann Bot 75:237-248.

Adhikari BS, Rikhari HC, Rawat YS, Singh SP (1991). High altitude forest: Composition, diversity and profile structure in a part of Kumaun Himalaya. Trop Ecol 32(1):86-97.

Bhandari BS, Mehta JP, Nautiyal BP, Tiwari SC (1997). Structure of a chir pine (Pinus roxburghii Sarg.) community along in altitudinal gradient in Garhwal Himalaya. Int Jour Ecol Env Sci 23(1):67-74.

Chadha SK (1998). Himalayas Ecology and Environment. Mittal publication, New Delhi.

Champion HG, Seth SK (1968). A revised survey of the forest types of India. Government of India publications, New Delhi.

Curtis JT (1959). The Vegetation of Wisconsin: An Ordination of Plant Communities. University of Wisconsin Press, Madison.

Dabel CV, Day FP (1977). Structural comparisons of four plant communities in the great Dismal Swamp, Virginia. Bull Torrey Bot Club 104:352-360.

Dhar U, Rawal RS, Samant SS (1997). Structural diversity and representativeness of forest vegetation in a protected area of Kumaun Himalaya, India: Implications for conservation. Biod Cons 6:1045-1062.

Duvugneaud P, Denaeyer De-Smet S (1970). Biological cycling of minerals in temperate deciduous forests. In: Reichle DE (Ed.). An analysis of Temperate Forest Ecosystems. SpringerVerlag, Berlin-Heidelberg-New York.

Franklin JR, Meada T, Ohsumi Y, Matsue M, Yagi M, Hawk GM (1979). Sub-alpine coniferous forests of central Honshu, Japan. Ecol Monogr 49:311-334.
55

Fredericksen TS, Mostacedo B (2000). Regeneration of sawtimber species Following selective logging in a Bolivian tropical forest. For Ecol Manage 131:47-55.

Garkoti SC, Singh SP (1994). Nutrient cycling in the three central Himalayan forests ranging from close canopied to open canopied treeline forests, India. Arc Alp Res 26(4):339348.

Hammer O (2002). Palaeontological community and diversity analysis-brief notes. Paläontologisches Institut und Museum, Zürich.

Heim A, Gansser A (1939). Central Himalaya: Geological observations of the Swiss expedition 1936, Schweizer. Naturf Ges Denksch 73(1):245.

Hussain MS, Sultana A, Khan JA, Khan A (2008). Species composition and community structure of forest stands in $\mathrm{Ku}$ maon Himalaya, Uttarakhand, India. Trop Ecol 49(2):167181.

Kanai H, Shakya PR, Shrestha TB (1975). Vegetation survey of central Nepal. University of Tokyo, University Museum Bulletin 415-423.

Knight DH (1975). A phytosociological analysis of species rich tropical forest on Barro Colorado Island, Panama. Ecol Monogr 45:259-284.

Kumar A, Sharma CM, Baduni NP (1997). Community structure and physical environment: A case study of the temperate mixed coniferous Lata forest in the Malari valley of Garhwal Himalaya. Jour Trop For Sci 9(4):449-457.

Kunwar RM, Sharma SP (2004). Quantitative analysis of tree species in two community forests of Dolpa district, midwest Nepal. Him Jour Sci 2(3):23-28.

Maguran AE (1988). Ecological diversity and its measurement. Princeton, University Press, New Jersey, EU.

Mani MS (1974). Ecology and Biogeography of India, Junk Publishers, The Hague.

Misra R (1968). The Ecology Workbook. Oxford \& IBH Publishing Co., Calcutta.

Mohan NP, Puri GS (1954). The Himalayan Conifers III-The succession of forest communities in oak conifer forests of the Bashahr Himalayas. Ind For 81:465-487.

Monk CD (1967). Tree species diversity in the eastern deciduous forest with particular reference to north central Florida. Amer Nat 101:173-187.

Muller-Dombois D, Ellenberg H (1974). Aims and methods of vegetation ecology. John Wiley and Sons.

Ohsawa M, Shakya PR, Numata M (1975). Forest vegetation of the Arun Valley, East Nepal, 99-143 p. In: Numata M. (Ed.). Mountaineering of Mount Makalu II and scientific studies in eastern Nepal.

Pandey SK, Shukla RP (1999). Plant diversity and community patterns along the disturbance gradient in plantation forests of Sal (Shorea robusta Gaertn.). Curr Sci 77:814-818.

Parker RN (1942). The ecological status of the Himalayan Fir forest. $150^{\text {th }}$ Anniv. Vol. Royal Botanical Garden, Calcutta. 
56

Puri GS, Gupta RK, Meher-Homji VM, Puri S (1989). Forest Ecology. Vol. II, Oxford and IBH Publication Co. Pvt Limited, New Delhi.

Rai ID, Adhikari BS, Rawat GS, Bargali K (2012). Community structure along timberline ecotone in relation to microtopography and disturbances in western Himalaya. Not Sci Biol 4(2):41-52.

Ralhan PK, Saxena AK, Singh JS (1982). Analysis of forest vegetation at and around Nainital in Kumaun Himalaya. Proc of Ind Nat Sci Acad. 48:122-138.

Reiners WA (1972). Structure and energetics of three Minnesota forests. Ecol Monogr 42:71-94.

Rikhari HC, Adhikari BS, Rawat YS (1997). Woody species composition of temperate forests along an elevational gradient in Indian Central Himalaya. Jour Trop For Sci 10(2):197-211.

Rikhari HC, Singh RS, Tripathi SK (1991). Pattern of species distribution, canopy characters and regeneration in major forest communities along an elevational gradient in central Himalaya. Int Jour Ecol Env Sci 17:167-174.

Risser PG, Rice EL (1971). Diversity in tree species in Oklahoma upland forests. Ecology 52:876-880.

Rochow JJ (1972). A vegetational description of mid-Missouri forest using gradient analysis techniques. Amer Midl Nat 87:377-396.

Saxena AK, Singh JS (1982). A phytosociological analysis of woody species in forest communities of a part of Kumaun Himalaya. Vegetatio 50:3-22.

Saxena AK, Singh JS (1984). The population structure of certain Himalayan Forest Associations and Implications concerning future composition. Plant Ecol 58(2):1-69.
Schmidt-Vogt D (1990). High altitude forests in the Jugal Himalayas (eastern central Nepal), Forest types and human impact. Geoecol Res 6:1-210.

Shannon CE, Wiener W (1963). The mathematical theory of communication. University of Illinois Press, Urbana, Illinois, USA.

Sharma E, Ambasht RS (1988). Nitrogen accretion and its energetics in the Himalayan Alder. Funct Ecol 2:229-235.

Singh JS, Singh SP (1992). Forests of Himalaya. Gyanodaya Prakashan, Nainital.

Singh JS, Singh SP, Saxena AK, Rawat YS (1981). The silent valley forest ecosystem and possible impact of proposed hydroelectric project. Report submitted to the Department of Environment, New Delhi.

Singh SP (1998). Chronic disturbance, a principal cause of environmental degradation in developing countries. Env Con 25:1-2.

Singh SP, Adhikari BS, Zobel DB (1994). Biomass, productivity, leaf longevity, and forest structure in the Central Himalaya. Ecol Monogr 64(4):401-421.

Upreti N, Tewari JC, Singh SP (1985). The Oak Forests of the Kumaun Himalaya (India): Composition, Diversity, and Regeneration. Moun Res Dev 5(2):163-174.

Whittaker RH (1960). Vegetation of the Siskiyou mountains, Oregon and California. Ecol Monogr 30:279-338.

Yoda K (1967). A preliminary survey of the forest vegetation of eastern Nepal. II. General description, structure and floristic composition of the sample plots chosen from different vegetation zones. J Coll Arts and Sci, Chiba Univ Sci Series 5:99-140. 